\title{
Initial Conquest of India by Turks and Their Slaves
}

\author{
Mustafa Sareer \\ Research Scholar Aligarh Muslim University Aligarh,Utter Pradesh 202002
}

The very word 'Turk' or 'Türk' appears as the name of a central-Asian nomad people only from the sixth century A.D. onwards. When in 552 the 'Turk' Qaghnate was founded on the Orkhon river in Mongolia. The Chinese name for the Turks was Tu-kuch, which was apparently derived from Türküt, The Mongol plural of Türk.The Greeks called them Tourkoi, The Arabs Atrak (sg.Turk), while in New Persian they became known as Turkan (sg.Turk). In Sanskrit they were called Turushkāh, while the Tibetians identified all Turks with the Qarlugh tribe, and hence referred to the Turks usually as Garlog. Originally,Türk was an ethnonym which was associated with a small tribe headed by the Ashina clan; it meant 'The Strong One' and fell within the semantic range of a whole series of tribal names which connoted 'Force', 'Violence', 'Ferociousness' and so on. These original Türks or Türkü had, in the first half of the fifth century, become vassals of another nomadic empire, that of the Juan-Juan. In the middle of the sixth century, however, the Turks destroyed the Juan-Juan empire while founding there own there own nomad state. This state reached at its greatest extent from the Great Wall to the Oxus and even beyond,covering therefore not only the whole of the inner and outer Mongolia but also settled areas far to the west. Intermittently it lasted upto the middle of the eighth century.

The origin of the Turks, as of other Central-Asian peoples, are obscure since the earliest tribal nomenclature is full of unresolved complexities, the evidence is scanty, fragmented and shrouded in legend. Byzantine and Chinese records of the early stages of the Turkish development are also exceedingly complicated and do not always supplement the earliest Turkish records in a sufficiently informative way. Just as the greek and Roman sources used the name 'Scythians' for a variety of 'Barbarian' tribes and the Byzantine sources used the name 'Turk' in the same loose way. So the Chinese used a word like 'hu' 'Barbarian' or a 'tribal' name like 'Hiung-nu', for various ethnic groups (which were moreover in constant flux). The idea prevailed in the Chinese accounts that the Turkish-speaking tribes of the seventh century were all descended from the Hiung-nu, which in practice meant little more than that they were neither Chinese nor Iranian. Al-Biruni, in his Kitab al-Hind, dates the beginning of the days of the Turks' (āyyām at-turk) from the time when they seized power in Ghazna under the Sāmāni dynasty and sovereignty fell to Nasir ad-Daula Sabuktigin. In all appearences this was an age when linkages between nomadic steppe populations of Central Asia and the sedentary civilizations of the middle East, China and India crossed a critical threshold whereby a series of conquests was set off which climaxed with the 'Mongol Storm' in the thirteenth century. These conquests were the result of an enhanced effectiveness of the social and military organization of the Central-Asian nomads which allowed them to transcend earlier tribal limitations. We also find, at this time, increasing numbers of detribalized Turks being imported into the Islamic world as military slaves. A situation arises hich saw the people of Turko-Mongol origin-rather than Arabs or Iranians- becoming the most important ruling elites of the Islamic Middle East and India henceforward. In the west, it was the Turks who took parts of Anatolia and Asia Minor from Byzantium, defying Latin Christianity (which responded with the crusades), and ultimately opening the way for the establishment of Ottoman power in parts of Europe. In the East, in al-Hind, the Turks added the Punjab and subsequently most of the Gangetic plain or Hindustan to the conquests of Islam, establishing the Sultanate of Delhi in the thirteenth century.

Originally, by definition almost, the Turks (including those that conquered India) came from Central Asia. The early Arabic texts often refer to all inhabitants of the Central-Asian steppes as Turks indiscriminately, but this is an area of which the boundaries are nowhere given. The expression 'Central Asia' is vaguely understood to refer the landlocked region between the Ukraine or Rumania, Hungary and the Chinese wall which is completely isolated from oceanic influences and hence is largely an arid and in part cold zone. In the fifth and sixth century the Turks are known to have been tributary to the Juan-Juan and to have served as their Blacksmith slaves and Iron workers. From the year 545 A.D. the Turks began to rid themselves of Juan-Juan overlordship. A year later their leader was in a position to demand a Juan-Juan princess in marriage. Ten years later the Turks had defeated the Juan-Juan decisively. Recognition by the western Wei was acquired soon. Bumin became the Turks first Emperor ruling from the Great Wall to the borders of Iran,as well as in the far north. A victory over the Hephthalites followed, and control over the entire steppe can now be said, for the first time to have been in the hands of a single ethnic group in the sense of a nomad human population with shared ancestry, myths, histories and cultures, having an association with a specific territory and a sense of solidarity. The most crucial date in the Turkish encounter with Islam is perhaps 751 A.D., the year of the battle of Talas river, when an alliance of Arabs, Tibetans and Qarlug Turks achieved a victory over the Tang Chinese. From that date onwards Turkish peoples began to assimilate within the sedentary Muslim world in considerable 
numbers. The Qarlugh Turks or 'Qarakhanids'(who may still have been claiming Ashina Descent) were the first to undergo almost complete sedentarization, after moving into Farghana, an area which in the ninth century was gradually becoming Islamicized. The Qarlughs established capitals at Kashgar in Sinkiang and Balasaghum in the valley of the Chu river. Their rulers converted to Islam after the middle of the tenth century, and in 961 A.D. This was followed by the conversion of some 100,000 Turkish 'Tents' in the area. More precise and reliable knowledge emerged among the Muslims by the ninth century, when the Samanids extended the frontier along the Syr Darya and Turks began to enter the Caliphate as military slaves.

There do not appear to have been any Turkish invasion on the North-western frontier or elsewhere, and we do not hear at all of Muslim Turks in al-Hind, before the late tenth and eleventh century.If we could identify various groups from central Asia which migrated into the subcontinent in earlier times, these were not the Turkish. The first real evidence of Turks in al-Hind comes from Kashmir during Lalitaditya Muktapida's reign. This king, while extending his powers into central Asia, is recorded to have recruited soldiers from the western Central-Asian highlands and Tukharistan. Al-Biruni has recorded that the people of Kashmir celebrated an annual festival to commemorate the victory of their king Muttai (Muktapida) over the Turks. Indian vernacular sources describe the conquest at length as 'The opening of the gates of Hind'.

While inscriptions in sanskrit which survived from these centuries frequently mention the violent erruptions of the Turushkas, the 'Country Conquering Turks', 'Beef-eating barbarians (mlecchas)' , 'Shaka princes', or at a somewhat later stage, of the 'Mongols' (Mudgalas). To piece together a coherent narrative to the conquest, however, from the late tenth to the early thirteenth century, would be impossible on the basis of the Indian materials alone. It is disconcertingly difficult even with the aid of the Arabic and Persian sources. The latter however, on the most basic level, deal with sequences of events (rather than individual events), and they allow us to distinguish two stages in the conquest: the first, commonly called, The Ghaznavid Period, from 977 to 1186 A.D. ; and the second, The Ghurid Period, from 1186 to 1206 A.D.

Mahmuds dynasty, The Ghaznavids or Yaminids (352-582/962-1186), was a Turkish stock; its effective founder, Mahmuds father Sabüktagin, had been a Turkish slave commander. At its greatest extent, the Ghaznavid empire embraced an area from Rayy and Isfahān in Persia as far as Hānsi in the eastern Punjab. Mahmud himself, who conducted no less than seventeen expeditions against Pagan Indian rulers and who also rooted out the Ismailis from the cities of Multan and Mansura, was rewarded by the 'Abbasid Caliph for his services to Sunni Islam with the laqab of Yamin-al-Dawla'("Right Hand of the State"). The main concern of the Ghaznavid Turks, from the beginning, appears to have been to penetrate into the major river valleys, of the Indus first,then the 'Five River Land of Punjab' and finally the 'Two River Land-The Ganga-Yamuna Doab'.The very earliest expansion towards east,into al-Hind began under Alptagin, in the period 933-963 A.D., when his general Sabuktagin raided Lamghan and Multan.

In the first year of his reign, in 977-8 A.D.,Sabuktagin also conquered Bust, the second most important fortified city in Sijistan (after Zaranj).Qusdar, another fortified Muslim town in Turan (Sind), which gave its name to an entire sub region, fell to the Ghaznavid in the same year and then the entire province of Qandhar. On a third occasion,in 991 A.D,the assembled army of a coalition of Indian Kings headed by the Hindu Shahi was dispersed, after which Ghaznavid power was established in virtually all areas of the west of the Indus. Sabuktagins son and successor Mahmud (r.998-1030), obtaining caliphal sanction (mauqif-i-Khilafat) for his actions, expanded the Ghaznavid empire as far as the Caspian Sea, and from Samarqand to Ray, while invading Hind about seventeen times and ultimately establishing permanent control over the Punjab. During renewed campaining into Lamghan, and to Peshawar (Ar. Parshawar), Waihind, on the road from Peshawar to Lahore, was taken from the Hindu Shahi. In 1004-05 followed the conquest of Bhatinda or Tabarhind, which,together with Bhatnair, Sirsa and Abahr,was one of the four important forts in the path of any invader from the NorthWest, and had to be reduced in order to gain access to the trans-Gangetic plain. Nagarkot (Bhima Naghara) was taken in 1008, and again Waihind. Much further inland (Al-Utbi says in the middle of al-Hind). The capture of Narayan (present Narayanpur, near Alwar,Rajasthan) appears to have been aimed at gaining another route of access to the Ganges- Yamuna Doab.Similarly, Nardin (Nandana, Nanduna) on the northern spur of the salt range in the Jud hills, still in the hands of a Hindu Shahi subordinate, was taken to gain command over the main route to the Doab,'the most glorious victory of islam since the time of the Prophet. When the Turkish armies, after opening these gates, finally broke through to the middle country, the Temple City of Thaneswar (Ar. Tanisar, Tanishar), to the north of Delhi, was destroyed first, probably in 1011 (The city was entered unopposed), then Mathura (Matra, Mahura, Matura)(also entered without opposition), on the Yamuna, then the capital city,Kanauj (Qanauj, Qannauj), which was still governed by a Pratihara ruler that Al-Utbi refers to as 'The pre-eminent Indian King' (muqaddam-i-muluk-i-hind). Mahmud returned to Ghazna after this, but in the fall of the same year 1019 crossed the Yamuna again,and now possibly for the first time,the Ganges, in attack on the Chandellas, by that time the most powerful rulers of the North India in Jejakabukti (Bundelkhand), Khajuraho, and Gwalior. Lahore was taken without opposition some year later. The forts of Kalanjar and Gwalior (Gwaliyar) were taken from the Chandella ruler in 1022-3. Somnath the wealthy harbor and pilgrimage 
centre in Saurashtra-Gujrat (which had been deemed safe behind the desert and boasted 'the greatest idol of alHind'), was destroyed in 1025-6. Mahmuds son and successor Masud(r.1030-41) did not abandon plunder raids and military campaigns deep into India, beyond the confines of the area which was now the formal Ghaznavid dominion under an investure patent sent from Baghdad in 1030-31. In 1030-31 a significant new initiative was the first invasion of Awadh under Sayyid Salar Masud Ghazi, a nephew of Mahmud, who had been born in 1015.From a military point of view, it was a complete failure, and hardly any of the invaders returned alive. An account of it is given in an historical romance written by a sufi, 'Abd ar-Rehman Chishti' during the reign of the Mughal emperor Jahangir entitled 'Mirat-i-Masudi'.This work is said by its author to have been mainly based on a book called the 'Tawarikh-i-Mahmudi' written by Mahmud Ghaznavi, a servant of Amir Sabuktigin and one of the followers of Sayyid Salar who related events of which he had personal knowledge. There are numerous tombs scattered all over the northern districts of Awadh,which are said to cover the remains of martyers of Sayyid Salars army. Bahraich was probably reached in 1033, and Sayyid Salar appears to have been able to repeatedly defeated the local rais on the bank of river Kosala(probably Kauriala), until reinforcements arrived in the Hindu camp and the 'Prince of martyrs' fell with virtually all his followers. Bahraich is still celebrated for the shrine of Sayyid Salar. Another successful attempt to seize the wealth of Banaras undertaken by a rebellious governor of the Punjab,Ahmad Nayaltigin, a son of Mahmud,in 1033.Nayaltigin joined by the ghazis and the army of Lahore crossed the Ganges and going down the left bank arrived at Banaras,' where no army of Islam had ever reached',plundering the markets and returning with great spoil. By 1033, the year of famine, it was becoming clear that the great age of Ghaznavid conquests was drawing to a close.The Seljuqs were rapidly emerging as the dominant power in the eastern Islamic world.

The Ghaznavids retained their possessions in the northern and eastern Afghanistan, as well as their Indian conquests for a century more,until the rise of the Ghurids.In the year 1079-80 there are reports of new campaigns under Ibrahim but the dates are not sure. Between 1066-1070,one of the Ibrahims sons appears to have led an army of Ghazis and 40,000 cavalry into the doab.Inscriptions of the Gahadavalas from 1090 mentions a tax, called the 'Turushkadanda', 'Turkish Punishment', which was possibly a defence tax (Turkenhilfe) or an amount which was set apart to be paid as tribute to the Ghaznavids.After the death of Masud III in 1118,however, Seljuq suzerainty was established over Ghazna.The real menace to the Ghaznavids came not from the Seljuqs but from the Shansabanis of Ghur.

Muizz-ud-Dins family, the Shansabanids, as designated by Minhaj-i-Siraj originated among the petty princes (muluk-sing. malik) of Ghur, the mountainous region east of Herat. The dynasty was designated as Shansabani's by Minha-i-Siraj as they descended from an ancestor named Shansab.In 12th century an event of supreme importance for the history of central Asia happened and it was the rise of Khwarizm and Ghor and their eventual struggle for the mastery of Khurasan. Atsiz, the founder of khwarizms greatness, was originally a loyal vassal of Sanjar until jealously the latter's courtiers drove him to open revolt in 533/1138. Sanjar defeated him and appointed his nephew Sulaiman to his office. As soon as Sanjar's back was turned Atsiz advanced and drove Sulaiman out of Khwarizm. Sanjar defeated him two more times in 538-1143 and 542/1147 respectively. Before Atsiz's death in 551/1156 he had annexed Jand and Mankishlagh and had imposed something like suzerainty over the Khan of Samarqand. Arsalan-II, the successor of Atsiz, followed his father's imperialist policy with steadfast resolution. He provoked the Qarakhitai's to invade his territories in 567/1172, first by siding with Khan of Samarqand in a conflict with Qarlughs and then by refusing to continue the annual tribute, Khwarizmi army was decisively defeated. In Khurasan the Khwarizm Shah failed to make much headway; the Ghuzz and lately, the Qarakhitai, arrested his efforts. His preoccupations, however provided opportunity to the rulers of the petty principality of Ghor, to extend their power quietly at the cost of the war leaders holding the province. From their insignificant position as the chiefs of the mountain fortress of Ghor, they came into prominence during the reign of Ghaznavid Bahram, who perfidiously murdered Malik Qutubuddin Hasan, a Ghorid prince who had taken refuge at his court and been married to one of Bahram's daughters. This roused the wrath of Saifuddin Suri, brother of the murdered prince, who thereupon invaded Ghazni and drove Bahram from the city. He soon returned in 543-1148 and taking advantage of the absence of the Ghoride troops, then wintering at home, seized Saifuddin and sent his head to Sanjar. Alauddin Hussain, Saifuddin's younger brother, then advanced on Ghazni and wreaked a terrible vengeance. After plundering the city he set fire to the buildings, which were left burning for seven days, and massacred the whole population. This action, which earned him the unenviable nickname of 'Jahan Soz' (The world Burner), and he took for himself the title of Sultan. It was Husayn's nephew Ghiyath-ud-Din Muhammad b. Sam (558-599/1163-1203), who expelled the Ghuzz from Ghazna in 569/1173 and installed there his younger brother Muizz-ud-Din (formerly Shihab-ud-Din) Muhammad. Under Ghiyath-ud-Din and Muizz-ud-Din, who throughout cooperated more or less harmoniously, the Shansabanids or Ghurids, since they had reduced to Subordinate Status the other maliks of the region emerged as one of the great powers of the Islamic world. Their political seat was the fortress of Firuzkuh, identified by Andre Maricq in 1957 with ruins at Jam on the middle Hari Rud, some $200 \mathrm{Km}$. east of Herat. Encouraged by the Caliph, from whom he obtained the title Qasim Amir Al-Muminin (Partner of the 
Commander of Faithful), Giyath-ud-Din engaged in a duel for Khurasan with the Khwarizmshahs, in which, prior to his death in 599/1203 the Ghurids definitely had the better of it. Muizz-ud-Din, who like Giyath-ud-Din bore the title of Sultan, ably seconded his bother's efforts; but he also looked eastwards.

The Ghurid conquest of Hind was initiated from Ghazna. Having defeated the Ghuzz at Ghazna in 1173, Giyath-ud-Din had placed the city in the charge of his younger brother Muizz-ud-Din, the future 'Conqueror of Hind' (Khursau-i-hindgir); who 'ascended the throne of Ghazna like Mahmud'. One difference was that Muizz-ud-Din received Ghazana as a family appanage. Once installed at Ghazna, Muizz-ud-Din was not slow to appropriate the Ghaznawids role as the standard bearer of orthodox Islam in the subcontinent. He made war on the Ismāilis in Multan and captured the city in (571/1175-6) and then captured Daybul in Indus Delta in 578/1182-3. Certainly he is praised for his warfare against the Shiis. The annexation of the remaining Ghaznawid territories was undoubtedly his principal goal. A series of campaigns from 577/1181-2 onwards secured first tribute from Khusraw Malik and then,in 582/1186, the capitulation of Lahore. Khusraw Malik was sent to Giyath-ud-Din and later put to death in captivity.The beginning of Turkish ascendency over the Islamic world was contemporaneous with the emergence of a new fighting order is Indian society. The Arab had to face Brahmin dynasty in Sindh, the Turks faced the Rajput. After the end of Harsha's empire in 7th Century saw a new aristocracy taking gradual shape. This was the 'Rajput' (not encountered in the Muslim sources before the sixteenth century) who for the next few centuries championed a resuscitated Brahmanism and controlled the destiny of North India. He had points of resemblance with the Turk. To both, the sword was the means of achieving glory; philosophical speculation held no attraction for either of them; clannishness and a blind loyalty characterized the two peoples; a kind of feudalism featured both the political systems. But the Rajput excelled the Turks in reckless bravery and a chivalrous sense of honor that led him to commit self-destruction rather than suffer defeat or go down in his own estimation.

The Arabs had faced an effete people in Sind, to the Turks was opposed this virile warrior race who ruled the country from the Siwalikh to the Vindhyas. But the Rajput thirst for military glory proved his nemesis, for it led to constant wars and to political disintegration. The Gurjara-Pratihara Empire had given a way to a multi-state system in which a ceaseless struggle for lord - paramountcy was the order of the day. Twelfth century India was indeed, a tempting prize for the land hungry Turks.

The nature had provided a narrow entrance to the Ganges valley (a belt of land not exceeding three hundred miles in breadth and skirted by the forbidding Himalayas and central India wilderness on either side) which is not difficult to guard. The Aravalli hills from the southwest and the Siwalikh (Sapadalaksha) from the north-east approach each other across the plain separating the Punjab from the Ganges valley, leaving a conveniently narrow gap not more than a hundred miles in width. Through this gap, or to use a commoner term bottleneck, alone, the Ganges valley or to use the name given by the Muslims, Hindustan could be approached militarily from the west. The ordinary route from beyond the Sulaiman mountains in those days was not the well-known Khaiber pass, nor the Bolan in the south, but through the Gomal, which led to Dera Ismail Khan and thence to upper Sind Sagar Doab. The Khaiber, Bolan and the less accessible Kurram and Tochi passes were not used by trading caravans to the same extent as the Gomal passage which was the normal military route.

Throughout the 13th Century the first point of attack for an invading army from beyond the Sulaiman range was Multan or Uch and not Lahore or Peshawar. From Ghazni the shortest route to Punjab was through the Kurram, Tochi and Gomal Passes and Khaiber involved a long detour through the north. Politically the Khaiber area was not safe.The tribes inhabiting the northern Sind Sagar Doab were perpetually hostile. His (Muizz-ud-din) earliest incursion into the Dār al-Harb had ended in disaster. Passing through Multan and Uchh in 1178/574, he struck across the Rajputana desert and arrived with an exhausted army at the foot of Mt. Abu where he found the fresh troops of Mularaja II waiting to oppose his progress. In the engagement, fought near hill of Kayadra. In an opposition which was not of Muizz-ud-din's choosing he suffered a signal defeat. It was the defeat not only of his forces but also of his plans. For him Hindustan now appeared to have only one practicable approach and the annexation of the Ghaznawid Punjab became more a strategic than a political necessity. The next few years accordingly found him making a determined and gradual advance through Khusrau Malik's dominion. Peshawar was taken in 1179; Sialkot fell in 1185, and Lahore, after three expeditions was finally occupied in 1186, and with his own governor installed at Lahore, he now found himself in possession of the Indus basin and in a strategic position to advance further into the fertile plains of India. His was only the most successful of the many attempts made by the Turks from the northwest to obtain a foothold in Hindustan all of which may therefore be regarded as preliminaries to Tarian. Muizz-ud-din brought to successful end a century of reconnoitering activity, a programme of military action of which he was not the conqueror. On these occassions the Muslim invaders were repeatedly repulsed.

The Chauhanas who ruled the territory extending from Ajmer to Delhi and thus guarded the entrance into Hindustan felt pressure of Muslim invasions. Durlava II of Sambher is said to have lost his life in fighting the Turks, Ajayadeva is credited with having repeatedly defeated the Muslim intruders. In the reign of Vigraharaja IV they advanced on Balbera (modern Rupnagar in Kishangarh). The Delhi pillar inscription of this 
kind dated V.S. 1220/1163A.D record his extermination of the malecchas and restoration of the country to the Aryas.A more definite evidence of the threatening advance of the Turks is furnished by an inscription of Prithviraja I recording the fortification of the frontier town of Hansi to check the progress of "the Hammira who has become the cause of anxiety to the world. The mention of Hansi along the Pakpattan indicates the tract through which the Turkish attacks were being delivered. Subsequently, at a date which is variously given as 583/1187-8 or 587-1191 Muizz-ud-Din invaded eastern Punjab and established a garrison at Tabarhindh (Bhatinda), situated about a hundred miles north of Hansi. He left Ziauddin of Tulak with 12,000 troops to hold it till his return. But Prithviraja in person and his subordinate Govindraja of Delhi recovered the fortress. In the battle fought near the village of Tarain, not far from the fort. In this battle Muizz-ud-din was decisively beaten. Prithviraj immediately invested the fortress but it took him thirteen months to force Ziauddin to surrender. Muizz-ud-din returned in 588/1192 and once more met his chauhana adversary on the field of Tarain. He divided his forces into five divisions, four of which engaged the enemy on all sides. At the end of the day the fifth division, kept in reserve, attacked the exhausted enemy and thus decided the issue, Khandi Rai (Govinda Rai) was killed and Prithviraja trying to escape, was captured near Sarsuti. and at Ajmer he was put to death. This victory laid the whole Chauhana kingdom at Muiz-ud-din's feet Hansi, Kuhram and Sarsuti, all places of military importance, were immediately occupied and garrisoned. This victory at Tarain also seems to have constituted a turning point in two respects. Firstly, the Hindu chiefs of the eastern Punjab undertook to pay tribute to Muizz-ud-din. And in the second place, it is from this moment that we can date the establishment of a permanent Muslim force in the region, at Indraprashta (Indrapat), near Delhi. But not on uniform basis. At Inderpat near Delhi an occupation army was stationed under the command of Qutubuddin Aibak who was to act as Muizz-ud-din's representative in India. The conqueror then returned to his central Asian projects (leaving Aibak with wide powers to consolidate and extend the conquests) where from he returned to India for each cold season to take charge of the war against the infidel.

In Ramzan 588/1192 Aibak defeated and slain a Hindu chief whom Hasan Nizami calls Jatwan in Bagar. He then crossed the Jumna to establish a military base in upper Doab. The greater part of the region was held, under the Gahadavalas, by Dor Rajputs with their strong hold at Baran. By treachery the Baran was captured. Meerut was also occupied and both the places were garrisoned and fortified and they became the spearheads of attack from the north on the Gahadvala dominions. The camp at Inderpat was clearly a temporary residence and could hardly satisfy the growing needs of a political capital. Ajmer situated well inside Rajputana, appeared unsuitable. Delhi was a better alternative, its situation and historical traditions provided the necessary features. In 589/1193 Aibak moved his forces against the Tomara ruler of city and occupied it with comparative ease. Delhi thus became the capital of Muizz-ud-din's Indian dominion. Aibak was busy in suppressing the Harriraja, the brother of late Chauhana king who besieged Ranthambhor and with dispossessed ruler of Delhi when according to Hasan Nizami, Aibak was sent to Ghazni by his master where he stayed for six months and on his return in 590/1194, Aibak crossed the Jumna a second time and captured Kol (Koil, Aligarh). Muizz-uddin assisted by the Aibak invaded Banaras, Whose ruler Jayachandra met them in the vicinity of Chandwar on the Jumna, between Kanouj and Etah. Jayachandra was defeated and killed in this battle. This victory added another great Kindgdom as far as Monghyr to the Shansabani empire. Malik Husamuddin Ughulbak became its first commandant (Muqti). Next year in 592/1195-6. Muizz-ud-din again came to India and moved against Bayana, the capital of the Jadon Bhatti Rajputs. Without any difficulty the city was conquered as the ruler do not give resistance. Then Thangir (Tahangarh) and fortified Vijayaymandirgarh were occupied and garrisoned under Bahauddin tughril. After that Muizz-ud-din captured the strong fort of Gwalior, held by the Parihara prince named Sallakshanapala, by Hasan Nizami.

In 592/1196 Aibak re-occupied Ajmer, thwarting an attempt by the tribal Mhers, in alliance with the dispossessed chauhans and Chalukyas, to retake it. In 1197, Aibak plundered Nahrwala (Anhilwara) in Gujarat, although the province was not subdued. In 594/1197-8, Badaun was captured followed by the second occupation of Banaras. Next year in 595/1198-9, "Chantarwal (Chandwar) and Kanauj were captured. The opening of the Thirteenth century saw the Turkish forces engaged against the last surviving imperial Rajputs of Bundelkhand (Jejakabhukti) and in 599/1202 Turks attacked Kalinjar the military capital of Paramardideva and conquered it and also its principal forts Mahoba and Khajuraho were then occupied and grouped into a military division under the command of Hasan Arnal. Badaun appears to have been the starting point for further conquests, first in Awadh, and then in Bihar and Bengal, undertaken by Muhammad bin Bakhtiyar (Ikhtiyaruddin) Muhammad Bakhtiyar. A Khaliji troop under the Malik Husammuddin Ughulbak, the commander of Banaras and Awadh division. Proceeding into Magadha, region east of the Karamanasa river he initiated raids into Maner and Bihar and obtained ample resources. Bakhtiyar obtained Aibak's commendation for a final attack on the monastery town which must have been Uddandapura Juzjani describes the whole of this fortress and city as a vihara, which he explains, is a madrasa' or 'place of learning in the Hindwi Language' inhabited largely by Shaven-headed brahmans', that is by Buddhist monks, which were all slain. Tibetan author of the early seventeenth century, Tarantha, in his 'History of Buddhism in India', writes that the Stag-gzigs', 'Turks' 'overran the whole of 
Magadha and massacred many ordained monks in Uddandapura. In the account of the Tibetan pilgrim Dharmasvamin, who visited eastern India in the years 1234-36, the vihara of Uddandapura is mentioned twice as the residence of a Turushka military commander.hammad bin Bakhtiyar, having received a robe of honour for his earlier victory from Aibak, again set out for Bihar and then to Nadiya or as Minjah calls it 'Nodia', a Sena capital, which he took possession of in May 1204, finally driving Lakhsmana Sena to Sankanat (what Juzjani refers to as Sankakot not far from Vikramapura, where Lakshmana Sena's descendants are archeologically recorded to have ruled for the next three generations) and Bang, where the latters reign soon came to an end.Muhammad bin Bakhtiyar left Nadiya in desolution, despatching a large part of its accumulated treasure to Aibak, and transferring the seat of Muslim government to Lakhnauti, a northern Sena capital on the Ganges near Gaur in Maldah district. Within two years from the raid on Nadia he began making preparations for a third adventure, an expedition to the northeast, to conquer "Tibet and China."Minhaj possibly hints at the real purpose of the expedition when he speaks of the trading routes, numbering about 35, that carried a brisk trade in Tangan horses from "Karambattan" (possibly Kumrikotah in Bhutan) and "Tibet" to Kamrup and thence to the districts of North Bengal. Bakhtiyar wanted to have monopoly of this important breed. From Lakhnauti he arrived, according to Minhaj, at 'Bardhankuti' whence for ten days he marched northwards along the river named Bangmati, "Three times as broad as the Ganges." He was badly crushed their and on the retreat at Devkot he was assassinated by one of his own lieutenants, named Ali Mardan.

At the same time the Muizz-ud-din was defeated at Andkhud in 601/1204 which provoked rebellions in various parts of the empire, and his last years were taken up with their suppression. On settling the affairs at Lahore, Muizz-ud-din left for Ghazni and on the way at Damyak while engaged in evening prayers, he met his death at the hands of an assassin, on 3rd Shaban, 602/march 15th, 1206. The murder was ascribed to Mulahida, a term applied for, Qaramitah and Ismaili Shaias and also to non-Muslims. The Turks had overrun the whole of north India, but on Muizz-ud-din's death found themselves in effective possession only of Sind and parts of the Punjab and the Gangetic valley with Rajput resistance increasing in extent. Muizz-ud-din left no son; his nephew Ghiuasuddin Mahmud showed no promise of leadership. Three among Muizz-ud-dins officers held important commands and nourished ambitions of sovereignty - Tajuddin Yalduz held Karman and Sankuran, Nasiruddin Qubachah a son-in-law of Yalduz and incharge of Uch. And most capable among them was Qutbuddin Aibak. After 2nd battle of Tarain, he was left incharge of Indian conquests Aibak in 1206, 24 June/17th Zilqad, 602 proceeded from Delhi to Punjab and ascended 'the Throne of the Sultanate of Lahore' (takht-i-saltanat-i-lohor). Ibn Battuta, exclude Qutubuddin Aibak, from the list of Muslim Kings of Delhi because the latter ascended the throne in Lahore and not in Delhi Aibak was given the title of Sultan' (laqab-iSaltani, Khitab-i-Saltāni) as well as the title of Bādshāh' (Khitāab-i-bādshāhi) and a canopy of state (chatr) and 'Staff' (dūrbash) in 1205 by Ghiyasuddin Mahmud when he became the Ghurid suzerain at Firūzkūh. Aibak did not issue any coinage in his name, but restricted himself in circulating coins as a local governor in the name of his suzerain. Aibak captured Ghazna and in the capital set on the imperial throne ( dār al-mulk-i-ghaznin bar takti-i-bādshāhi) for forty days in the year 1208 A.D. The oldest Muslim inscription in Palwal, of that year, refers to Aibak as 'riqāa al-Imām Saiyid at-turk wa-l-'ajam', The master of the rulers of the Turks and the Persians'. Died in 607-1210 of injuries received in a fall from his horse while playing chaugan, Aibak contested many battles in Hindustan but as a Sipāhsālār or 'Chief Commander' of the army in Hind, and none is recorded in the four years between 1206 and his death in Lahore in 1210-11.

After Aibak, his adopted son, Arām Shāh ruled for less than a year in 1210-11. He also did not issue any coinage and is not mentioned by Ibn Batuta in his list of Delhi Sultans. He was defeated by Iltutmish Governor of Badaun (Slave of Aibak, and hence the slave of a slave) who was invited by the citizens of Delhi on the death of Aibak. At this time as Juzjani writes, the dominions of Hindustan (mamālik-i-hindustān) became divided in four parts: the 'mamlakat-i-dihli' which went to Iltutmish, the 'mamlakat-i-lakhnauti' which was brought under subjection by the Khalaj Chiefs, the mamlakat-i-sind which was taken by Qabacha, and the 'mamlakat-i-lohor' which was seized 'sometimes by Qabacha and sometimes by Iltutmish'. All the three sovereigns were engaged in a contest for primacy which was ultimately won by the Delhi ruler- Iltutmish.

In the words of Ibn Batutah, Sultan Shamsad-Din Iltutmish who became 'the first who ruled in the city of Delhi with independent power. Iltutmish conquered many territories and expanded the Delhi Sultanate. He conquered the territories in the Chinab and Jehlum valleys. Uch, Bhakar, Lahore, Twelve celebrated fortresses in Debal (Hassan Nizami), Siwistan (Sehwan) lak (Lakki Pass,) Nandanah in Salt Range (recorded by Minhaj), Bihar, Lakhanauti, First in 624/1226-7 (by iltutmish's son and then in Nov. 8. 1230.) Ranthambhor, Mandor, Bayana, Thangir, Lawah, Kasili,Sambhar, Malwah, Bhilsa, Ujjain-in 632/1234-5. Gwalior in 629/1231.

Iltutmish, like the later Delhi monarchs in his inscriptions uses the title 'maula muluk al-arab wa-lajam' ('King of the kings of the Arabs and the Persians'), which had been used already by Masud, as well as by earlier Muslim kings in view of their conquest of the non-Arab nations which they styled 'ajami'. He also uses the title 'maula muluk al-turk wa-l-ajam' as well as 'Saiyid as-salatin at-turk wa-l-ajam' (Master of the kings of the Turks and the Persian) or 'riqab al-imam maula muluk at-turk wa-l-ajam' and also 'Hindgir', '(Conqueror of 
Hind'), 'Shah-i-Sharq', ('King of the East') (at his death in 1236) and 'Saltan Saltatin ash-sharq', ('The Sultan of the Sultans of the East'). The latter title occurs with Iltutmish for the first time, as does the title 'Shahanshah',('King of Kings'), which had been associated with the emperors of Persia. Iltutmish was the first ruler is India to receive sanction for his rule from the Abbaside Caliph in Baghgad whose emissaries he received on 22nd Rabi, I, 626/19th February 1229. He introduced a new coinage system which remained essentially the same up to 1387; the silver tanka of one tola weight (172 gm) and the copper jital, distinct from Delhiwalas as well as the fractional coins of copper. Shamsuddin Iltutmish died on 20 Shaban 633/29 April 1236 of an illness contracted during his expedition to the northwest. He took up Aibaks unfinished work and against heavy odds and on imperfect foundation, built up a state whose sovereignty required great diplomatic skill to presence. A calculating and skill full organizer, to him the sultanate owed the first outline of its administrative system. Aibak outlined the Delhi Sultanate and its sovereign status; Iltutmish was unquestionably its first king who made the kingship hereditary for his children.

The Ghurid annexation of Indian territories was not merely for loot and plunder as their predecessors had done before, but the Ghurid conquest of India was done with proper planning, as it increased their wealth and also they do not let the conquered territories to slip out of there hands. They do not conquered the rural areas as they were less important and having less wealth within them. The Ghurid conquered the much important towns, cities and the places having some strategic position whether laying on a trade route, nearness to some important town or city,places of military importance like Hansi,Kuhram,Sarsuti or a place from where the Ghurids found it easy to conquer the other areas like Baran,Meerut became the spearheads of attack from the north on the Gahadvala dominions.

By following this strategy they annexed the most important areas of Dar-ul-Harab or Hindustan as muslims called it and they developed them more and more,the towns got developed into cities, cities into metropolitans, headquarters got developed into provincial headquarters etc. and thus the urbanism developed in India with the muslim conquest.

\section{Endnotes}

H.Escedy,'Tribe and Tribal Society in the $6^{\text {th }}$ Century Empire',Acta Orientalia Hungarica,25 (1972); P.B.Golden,' 'Imperial Ideology and the Sources of Political Unity amongst the Pre-Cinggisid Nomads of Western Eurasia', Archivum Eurasiae Medii Aevi,II (1982),pp.39-62; idem,History of the Turkic Peoples, pp.115-53.

H.Hoffmann,'Die Qarluq in der Tibetaischen Literatur',Oriens,III,2 (1950),pp.190-208.Cf.Wink, Andre,Al-Hind,The Making of the Indo-Islamic World,Vol. II,The Slave Kings and The Islamic Conquest 11th13th cen.,Oxford University Press(1999),p.60.[Hereafter Al-Hind,II]

G.Clauson,Turkish and Mongolian Studies(London,1962),p.1-3,6,11,14.

Ibid,p.8-9,11.

Al Biruni,Kitab fi Tahqiqi mali-I-Hind (Hyderabad,India,1958),p.16[Hereafter Al Biruni,Kitab al-Hind]

Definitions of Central Asia vary a great deal with different scholars,as do those of Inner Asia. A.M.Khazanor, for instance, refers Central Asia merely as the area which is flanked in the north by the Aral Sea and the Kazakh steppes, in the south by the Kopet-Dagh and Hindukush, in the west by the Caspian Sea, and in the east by the Pamirs' (Nomads and Oases in Central Asia; in J.A. Hall and I.C. Jarvie (eds), Transition to Modernity: Essays on Power, Wealth and Belief (Cambridge,1992),p.69). In Sinor (ed)., The Cambridge History of Early Inner Asia (Cambridge,1990). On the other hand, there is the concept of Inner Asia, which is equated with the Central Eurasia, and both of these are defined as cultural rather than geographical concepts; thus, the boundaries of this area fluctuated because the essential historical feature of Central Eurasia/Inner Asia, as Sinor sees it, is that its socities were usually characterized predominantly by pastoral nomadism rather than sedentary agriculture. In this conception, Seljuq - Turkish Anatolia in the eleventh century,for example, becomes part of Inner Asia in so far as nomads displace a Byzantine agricultural peasantry. Muta is mutandis, this should apply to Iran in the thirteenth century as well.

L.Kwanten, Imperial Nomads: a History of Central Asia,500-1500(Philadelphia,1979),p.20, 32; C.I. Beckwith, 'Aspects of the Early History of the Central Asian Guard Corps in Islam',Archivum Eurasia.Medii Aevi,IV(1984), p.32; Golden,P.B.'Imperial Ideology and the Sources of Political Unity amongst the PreCinggisid Nomads of Western Eurasia',Archivum Eurasiae Medii Aevi.II (1982),p.42-43; Codrington,K.de.B., 'A Geographical Introduction to the history of Central Asia', The Geographical Journal, CIV (1944), p.86.

This definition of an ethnic community is proposed by A.D.Smith, The Ethnic Origins of Nations(Oxford,1986),p.32 and adopted for the Turks by Golden,P.B.,An Introduction to the History of Turkic Peoples: Ethnogenesis and State formation in Medieval and Early Modern Eurasia and the Middle East (Wiesbaden,1992),p.1-2.Such community does not need to be able to refer to a common biological descent; in fact,they are always 'polyethnic' and political in character, with members who were born into it as well as 
others who joined it, a community of 'descent through tradition' and through recognition of the political leadership of a charismatic clan.

Stein,M.A. (ed),Kalhana's Rajtarangini (Delhi, 1960),IV,p.131-64;Wink Andre,Al-Hind: The Making of the Indo-Islamic World,I.Early Medieval India and the Expansion of Islam,7th-11th centuries (Leiden,1990).p.239-243.[Hereafter Al-Hind,I]

\section{Al-Biruni,Kitab al-Hind,p.486}

Cf.Harishchandra,Bharat-durdasha,Act 3,in: R.S.Mc Gregor, Hindi Literature from its Beginnings to the Nineteenth Century (Wiesbaden, 1984),p.3.

Other terms that are used include Tajika and Yavana (Ionians).On the term mleccha, see T.R.Sharma, Personal and Geographical Names in the Gupta Inscriptions (Delhi, 1978),p.149-52. For the use of Tajika or Tayi, see J.Newman, 'Islam in the Buddhist Kalacakra Tantra' (Paper presented to the 1989 Annual Meeting of the American Academy of Religions, Annaheim,CA.1989), and D.C.Sircar, Studies in the Geography of Ancient and Medieval India (Delhi,1971),p.126-7,131. For 'Shaka Princes', see Epigraphia Indica, Arabic and Persian Supplement,1913-14 (Calcutta, 1917; reprint Delhi, 1987),p.35-45. For Mudgalas,see G.Buhler, The Jagaducharita of Sarvanada: a Historical Romance from Gujrat (Vienna,1892),p.19. For Yavanas, see Sircar, Studies in Geography,p.396; Epigraphia Indica,III, p. 338-9; A.K. Narain , The Indo-Greeks (Delhi,1980),p.165-9.

C.E.Bosworth,'The Imperial Policy of the Early Ghaznavids',Islamic Studies 1 (1962), part 3, p.49-82, represented in his Medieval History.For a brief survey of the dynasty, see B.Spuler, 'Ghaznavids', Ch.Pellat et al.(eds.), The Encyclopaedia of Islam,new edition (Leiden,1954- in progress). The standard works are Bosworth, The Ghaznavids. Their Empire in Afghanistan and Eastern Iran 994:1040, $2^{\text {nd }}$ edition (Beirut, 1973); idem, The Later Ghaznavids,Splendour and Decay: The Dynasty in Afghanistan and Northern India 1040-1186 (Eidenburgh,1977).

Al-Hind, I, p.126.

Al-Utbi,Tarikh al-Yamini (Delhi, 1847),p.20-21,23[Hereafter Al-Utbi];Al-Utbi, Tarikh al-Yamini: Persian translation by Jurbadqani(1206 AD) (Tehran,1334 H),p.33-35[Hereafter Jurbadqani]; Tarikh-i-Farishta (Lucknow,1864),p.18-19; Alami.A, Conquetes de Mahmud al- Ghaznawi d'apres le Kitab al Yamini d'Utbi,2 vols (Doctorat d'Etat,Paris, III,1989).p.93-9. [Hereafter Alami.]

Al-Utbi,p.26; Jurbadqani,p.38-39,152; Tarikh- i- Farishta (Lucknow, 1864),p.19-20;Al- Hind,I,p. 126,216.

Al-Utbi,p.161-3; Jurbadqani,p.138-9; Tarikh-i-Farishta (Lucknow,1864),p.23;M.Nazim (ed.),Zayn al-Akhbar of Gardizi (Berlin, 1928),p.62.[Hereafter M.Nazim]

M.Nazim ,p.63,65; Alami,I,p.400-3， 405-16; Al-Utbi,p.179; Jurbadqani,p.155-6; Tarikh-i-Farishta (Lucknow, 1864),p.24; Al-Hind,I,p.126.

Tarikh-i-Farishta (Lucknow, 1864),p.26-27; ${ }^{1}$ Al-Utbi,p.278-86; Jurbadqani,p.187-8; M.Nazim ,p.69; Alami, II p.454-57.

'Tawassut dyar al-hind','waista mamalik-i-hind' (Al-Utbi,p.303;Jurbadqani,p.198.)

Al-Utbi,p.329-36; Jurbadqani,p.210-2; Tarikh-i-Farishta (Lucknow, 1864),p.28; M.Nazim,p.72; $\quad$ Alami,II ,p.500-17.

Al-Utbi,p.336-8; Jurbadqani,p.213-4; Tarikh-i-Farishta $\quad$ (Lucknow, 1864),p.27-28; Sachau,E.C.(trans.),Alberuni's India (New Delhi,1983),p.117; M.Nazim,p.71-72; Alami,p.484-91.

Al-Utbi,p.395-400; Jurbadqani,p.242-4; Tarikh-i-Farishta (Lucknow,1864),p.29; M.Nazim,p.75-76; Alami,II ,p.525-8.

Jurbadqani,p.244-5; $\quad$ Al-Utbi,p.400-1; $\quad$ Tarikh-i-Farishta $\quad$ (Lucknow,1864),p.29; $\quad$ Al-Hind,I,p.286,290; Alami,II,p.528-32.

Al-Utbi,p.415; Jurbadqani,p.251-2; C.J.Tornberg (ed.),Ibn al-Athir, Al-Kamil fi l-Tarikh, 12 vols (Leiden,18531869),VII,p.301[Hereafter C.J.Tornberg]; Tarikh-i-Farishta (Lucknow,1864),p.31; Al-Hind,I,p.286; Alami,II,p.547-58.

M.Nazim,p.78-79; Tarikh-i-Farishta (Lucknow, 1864),p.31; Alami,II,p.562-6.

M.Nazim,p.79-80; Tarikh-i-Farishta (Lucknow, 1864),p.31; Alami,II,p.566-71.

Al-Hind,I,p.68,185,218,307; Tarikh-i-Farishta (Lucknow, 1864),p.32-35;C.J.Tornberg,IX,p.241-2,345-6; M.Nazim,p.87-88;Alami,II,p.571-85.

Gazetteer of the province of Oudh. 3 vols (Lucknow and Allahabad,1877-78),III,p.487

Gazetteer of Oudh,I,p.112.

Cf.T.Mahmood, 'The Dargah of Sayyid Salar Masud Ghazi in Bahraich:Legend,Tradition and Reality',in: Ch. Troll (ed.),Muslim Shrines in India (New Delhi,1984).

W.H.Morley (ed.),Tarikh-i-Baihaqi (Calcutta,1862),p.323-9,495-8,500-38.

Al-Hind,II,p.126. 
Bosworth; Later Ghaznavids,splender and decay:the dynasty in Afghanistan and Northern India 10401186(Edinburgh,1977),111-22[Hereafter Bosworth,Later Gaznavids] ,p.61-68; Tarikh-i-Farishta (Lucknow, 1864),p.48-49;C.J.Tornberg,X,p.72-74.

A. Maricq and G. Weit; Le minaret de Djam. La decouverte de la capitale des sultans Ghorides (XII-XIII siecles) (paris, 1959),p 31-44, contain a historical survey of the dynasty down to C. 1200; Cf Jackson Peter;The Delhi Sultanate,A Political and Military History, Cambridge University Press, 1999, more generally, see C.E. Bosworth,The Early Islamic History of Ghur,Central Asiatic Journal,6 (1961); Ch.Pellat et al.(eds.),The encyclopaedia of Islam,new edition (Leiden,1954); A.D.H. Bivar, 'Ghur' ibid. For what follows, see also Bosworth; Later Ghaznavids,p.111-22; idem, 'The political and dynastic history of the Iranian world (A.D. 1000-1217)', in J.A. Boyle (ed). The Cambridge history of Iran, V. The Saljuq and Mongol periods (Cambridge, 1968), 157-66, 185-92.

.J.Tornberg, XI, p. 168.; Juwaini Alauddin Ata Malik;Tarikh-i-Jahan Gusha-e-Juwaini,ed. Abdul Wahab Qazwini.2 vols.,London,Gibb memorial series,1912-1916.Vol.III a facsimile edition,by E.D.Ross,London,1931.Eng trans.J.A.Boyle,2 vols,Manchester,1958, places the event in 565/1169.[Hereafter Juwaini], Cf.A.B.M. Habibullah, Foundation of Muslim rule in India, Allahabad, 1961; p. 105.[Hereafter Habibullah Foundation].

Juwaini. II, p. 10 for these periodical conflicts in which the help of Qarakhitai and the Seljug or the Khwarizm Shah was invariably sought by the two contending parties, see Bartold;Turkistan down to the Mongol Invasion,Eng. Trans. By H.A.R. Gibb,London,1928,2 ${ }^{\text {nd }}$ ed.1958 op.cit, p. 333ff.[Hereafter Bartold]

C.J.Tornberg, Xi. P. 168; Juwaini, idem, places the event in 565/1169, but Bartold upholds the above date.

Hamdullah Mustaufi Qazwini; Tarikh-i-Guzidah,Fascimile ed.,Gibb Memorial series, London, 1913,p. 460,[Hereafter, Guzidah];Al-Rawandi Abu Bakr Muhammad. b.Ali;Rahatus-Sudur ed,M.Iqbal,Cambridge,1922, p. 175.[Hereafter, Rawandi]

Minhaj,Abu Umar b. Siraj Juzjani;Tabaqat-i-Nasiri,(a) ed.Nasau Lees, Khadim Hussain,and Abdul Hai Bib.Ind.Calcutta,1864.(b)English trans.By H.G.Raverty,2 Vols,Bib.Ind Calcutta,1897, p. 55 ff.[Hereafter,Minhaj] It is not certain who was the antagonist of Alauddin at Ghazni for the accounts are not unanimous as to the date of Bahrams death and the accession of his son, Khursau.Minhaj, p. 24-5, states that Bahram was driven out of Ghazni by Alauddin, and places his death in 552/1156. An anecdote on p. 115, however implies that it was khusrau who apposed Alauddin, Guzidah, I, p. 406, and C.J.Tornberg, xi, p. 85, date Bahram's death in 544/1149 and 548/1153, respectively.Baizawi,Abu Said Abdullah;NizamatTwarikh.Bm.Add.16708.f.51a, states Bahram died before Alauddin's march on Ghazni, which must have occurred soon after 544, the year in which Saifuddin's head was sent to Sanjar.Cf Habibullah Foundation. C.J.Tornberg, xi, p. 74. places Alauddin's sack of Ghazni after his defeat by Sanjar in 547, which seems improbable. He further state that Alauddin placed his brother Saifuddin on the throne of Ghazni and on bahram Subsequently murdering the latter, once again marched to sack the city. But Bahram died in the meantime and his successor Khusrau had fled to Punjab. Guzidah supports this but confuses Khusrau with his son Khursrau Malik, last of the Ghaznawids. According to Minhaj, Khursrau left Ghazni only on the approach of the Ghuzz who then occupied it for 10 years. The dates 552/1157 and 555/1160 for the accessions of Khusrau and his son, Khusrau Malik, quoted by Raverty: op. cit, p. 114, note from their suppositious coins described in a manuscript entitled Tafsil-i-Sikkah, do not prove anything, since the legends given their in are fictitious and the works was admittedly compiled late in the 18 Century.

A.M. Husain (ed).; Futuh-us-Salatin of Isami (Agra, 1938).

Fakhre Mudabbir(Muhammad b. Mansur b. Said Qurashi);Shajarat (or Bahr) al-Ansab, partial edn. by Sir E. Denison Ross;Tarikh [sic]-i-Fakhr al-Din Mubarakshah (London,1927), 19-20. Habibullah, Foundation, 36-7. S.H. Hodivala, Studies in Indo-Muslim history (Bombay, 1939-57, 2 vols), I, 141, for Daybul, See S. Qudratullah Fatimi; 'The Twin Ports of Daybul', in Hamida Khuhro (ed.), Sind through the centuries (Oxford and Karachi, 1981), 97-105; Al-Hind, I,p. 181-3.

For this term see. B.D. Chattopadhayaya; 'Origin of the Rajputs: the political, economic and social processes in early medieval Rajasthan', IHR 3 (1976), 59-82, repr.in his The Making of early medieval India (Oxford and Delhi, 1994), 57-88.

For an account of the dynasty achievements see Majumdar; The Gurjara - Pratihara Empire.

On one or two occasions when Muizzuddin came to Peshawar he might have used the Khaiber, but the southern routes were more convenient. The troops of the Khwarizan Shah, with a view to capture Yalduz, the rulers of Ghazni, in 1215, are stated to have seized the frontier routes into Hindusthan, "Leading towards Gardiz and Karaha pass", that is the Kurram valley; Yalduz had to take a more southeasterly route, through the 'Sang-iSurkh' mountains, which according to the Reverty, op. cit. p. 505, is the name given to three or four passes; Minhaj p. 135. Through the province of 'Karman and Sankuran,' the old name of the tract between the Salt Range and Gardiz south of the 'Safed Koh', passed the lower route into Hindustan usually used by Muizz-uddin; Minhaj, p. 132; Raverty. Op. cit pp. 498-9; see also Raverty,H.G; Notes on Afghanistan,London,1880. pp. 
80-84. It was probably within this area that the passes of the "Sang-i-Surkh" (Red Mountain) were situated through which both Yalduz and Aibak retreated from Ghazni. Minhaj, p. 194-35; Sec also Raverty; Notes on Afghanistan, pp. 38-9; Trans. Tabakat-i-Nasiri, p. 538, note.

Minhaj, p. 116. It mentions Bhima as the reigning king of Anhilwara, but inscriptions and other Hindu records ascribe this victory to Mularaja II; Indian Antiquary, 1877, p. 186 and 198. See also Forbes,A.K.,Rasmala:Hindoo Annals of the Province of Goozerat in Western India,2 vols (London, 1924). (ed. Rawlinson) I, p. 199; Ojha,Gourishankar.H; Rajputaneka Itihasa,Ajmer,1927, i, p. 220. Cf. Ray,H.C.; Dynastic History of Northern India.3 Vols.Calcutta University 1931-35, ii, p. 1004-5, A fragmentary inscription at Kiradu near Mt. Abu, dated V.S. 1235 (1178 A.D. records the repair of a temple broken by a Turushka army, possibly referring to Muizz-ud-din's invasion, Epigraphia Indica, xi, p. 72).

N. Lees etal.; (eds) Tabaqat-i-Nasiri of Abu Umar al-Juzjani (Calcutta, 1894), p. 116-18; Ferishta,Qasim b. Hindu Khan;Tarikh-i-Ferishta (Lucknow, 1864), p. 52-57; A.M. Husian (ed); Futuhus-Salatin of Isami (Agra, 1938), vs. 1315-22[Hereafter Isami]; I.H. Siddiqui; Perso-Arabic Sources of Information on the Life and conditions in the sultanate of Delhi (New Delhi, 1992) p. 57.

N. Janardan Kirtane; 'The Hammira Mahakavya of Nagachandra Suri', Indian Antiquary (1890), p. 202, 21517.

Ojha; Rajputana, i. p. 266.

Indian Antiquary, 1890, p. 202; Sarda,H.N; Ajmer,Historical and Descriptive.Ajmer,1911.p. 79.

Indian Antiquary, 1890, p. 215-17.

1 Indian Antiquary, xii, p. 17. Thomas,Edward;Chronicles of the Pathan Kings of Delhi,London1871, p. 59, [Hereafter,Thomas Chronicles] noticed a coin of one Kilhana with the Arabic legend reading 'Sina' on the observe, which, according the him, is found only on the coins of Masud III. Kilhana in that case must originally have been Masud's feudatory who had latter rebelled and fortified the route from Pakpattan.

Ishwariparasad;History of Medieval India,Allahabad,1925, p. 177, states that Sirhind, in Patiala, 100 miles n.w. of Karnal was the first place captured. He relies on the printed text of Minhaj, p. 118, which has Sirhindah and in this is supported by later histories of like the Anonymous;Mirat-i-Jahan Numa,B.M.Or.1998 f. 50a, and Nurul Haqq Dehlavi; Zubdatul-Twarikh,I.O.1805 f.7b.(Cf Habibullah Foundation),Ferishta and Bakshi, Nizamuddin; Tabaqat-i-Akbari,(a)ed.De and Husain,3 Vols,Calcutta,1927-41.(b)Trans.B.De.3 Vols Cal.191340, however have Bhatindah; Ferishta, i. p. 5 and 7; Tabaqati-i-Akbari,i. p. 37 Raverty, op. cit, p 457, note 3, however informs us that in all the Miss. Collated by him it is written Tabarhinda, which is also found in Sirhindi,Yahya;Tarikh-i-Mubarakshahi,(a)ed.M.Hidayat Husain , Bib.Ind. Calcutta , 1931. (b)Eng. Trans.by K.K.Basu,Baroda,1932 p. 7, Badauni, i. p. 49 and Haji Dabir, ii, p. 677.Habibullah opines that no such place is known to have ever existed no one acquainted with the hurried style of writing Persian Characters can fail to see that transposition of a few dots and a careless joining of letters are all that is required to make Bhatindah read Tabarhindah and even Sirhind.Sirhind seems to be very improbable,for the shortest route from Lahore to Hindustan lay through western Patiala in which Bhatindah is situated. No remains of any strong fort, such as that which withstood Prithviraja's assault for over a year, were found in Sirhind. On the other hand in Bhatindah, Garrick noticed a strong massive fort and also heard local legends respecting Muizz-ud-din's attack on the place; Cunningham Reports, xxiii, p. 2-3. According to Raverty, op. cit; p. 458, note, the Lubbut-twarikh$i$-Hind, states that "Tabarhindah is now known as Bhatindah". But Ishwariprasad asserts that Shirhind was known as Bhatindah.Cf Habibullah,Foundation.

${ }^{1}$ (Minhaj, p.119).

${ }^{1}$ Minhaj, p. 118. Ferishta, pp. 5-7 and Tabaqati-i-Akbari, i. p.37, state that is was fought at Narain, near Tarain, "in the district of Sirsuti.").

${ }^{1}$ For details of the Tactics followed see Tarikh-i-Mubarak Shahi, p.9).

${ }^{1}$ Minhaj p. 120.

${ }^{1}$ Hasan Nizami;Tajul-Maasir(a)I.O.1486,(b)I.O.209,(c)B.M.Add.7623,(d)Add.7624, f. 44b. Minhaj states that he was immediately executed. For the absurd story of Chand Bardai of how prithviraja, blinded and kept in conferment at Ghazni, was yet able with the help of Chand himself, to slay Muizz-ud-din before his own execution, see Chand Bardai;Prithviraja Raso,ed.M.V.Pandia and Sam Sundar Das,Nagari Pracharini Sabha, Benaras, 1913 vi: also Raj Darshani, f. 49a.

Minhaj, p.120; Fakhruddin Mubarakshah,(Known as Fakhre Mudabbir);Tarikh-i-Fakhruddin Mubarakshah,ed.E.D.Ross, London, 1867, p. 22).

Ibn al-Athir,Izzal-Din,al-Kamil fi'l-Ta'rikh,ed.C.J.Tornberg; Ibn-El-Athiri Chronicon quod perfectissimum inscribitur (Leiden,1851-76,12 vols.); repr.(with different pagination) Dar al-Sader (Beirut,1386/1966,12 vols.)(references are to both editions,in that order), XI, 115/174, wa-iltazamu lahu bil-awwal.Cf.Jackson Peter; The Delhi Sultanate,A Political and Military History, Cambridge,1999; Tajul Maathir. Fol. 50b. for the chieftains of the Delhi region specifically(Cf Habibullah Foundation) 
${ }^{1}$ Tajud Din Hasan Nizami’s;Taajul-Maathir(The Crown of Glorious Deeds),translated by Bhagwat Saroop,saud Ahmad Dehlavi,Delhi,1998.[Hereafter Bhagwat Saroop Taaj-ul-Maathir],p.70.

${ }^{1}$ Bhagwat Saroop Taajul-Maathir,p.101.

${ }^{1}$ Bhagwat Saroop Tajul-Maathir,p.84.

${ }^{1}$ Minhaj, p. 139, dated the capture of Meerut in 587/1191, but he is more correct in assigning it to 588/1192, on p. 120).

${ }^{1}$ Bhagwat Saroop Tajul-Maathir,p.101. places the conquest of Delhi towards the end of 588/1192, as is done also in Minhaj, p.120, Tarikh-i-Mubarakshahi, p.11 Tabaqat-i-Akbari, i.p. 38-39, and Ferishta, I, p.58. Thomas read the date on the Qutub Minar inscriptions as 587. Thomas Chronicles, p.22. But this may also be read as 589.

${ }^{1}$ Bhagwat Saroop Tajul-Maathir,p.114. Ibn Battuta;Kitabur Rahlah,also called,Tuhfatun Nuzzar fi gharaib-ilamsar:ed.(a)Cairo,1870-71, (b)With a French trans.Defremery and Sanguinatti,Paris, 4 Vols, 1853-59, (c) Abridged Eng. Trans.H.A.R. Gibb,London,1929, (d) Eng.trans.(of the travels in India,Maldive and Ceylon) by Mahdi Husain,Baroda,1953, ii, p. 19-20, relates a curious story of how his master summoned him secretly to confound his enemies who accused him of disloyalty.

${ }^{1}$ Bhagwat Saroop Tajul-Maathir,p.146. Minhaj places it in 589; p. 120.

1 Bhagwat Saroop Tajul-Maathir,p.151.Mulla Ahmad Thattawi and others, Tarikh-i-Alfi,B.M.(a) Or, 142,(b) Or, 162. f. 485, states that Jayachandra with an army of hundred thousand horses and seven hundred elephants, was himself marching against Muiz-ud-din Territories(Cf Habibullah Foundation).

${ }^{1}$ Written Kanwar Pal by Bhagwat Saroop Taajul-Maathir,p.201.; Kumarapala is mentioned in the annals of the ancestors of the Jadon Bhatti dynasty of Kerauli, Cunningham; Reports, xx, p. 67-8.

${ }^{1}$ Bhagwat Saroop Tajul-Maathir,p.201. Minhaj, p. 114, dates the event in 591/1195, but Fakhre Mudabbir p. 23, confirms Hasan Nizami. A locally current couplet in Hindi has preserved the date and name of the Muslim officer, Cunningham; Reports, VI, p.55.

1 Bhagwat Saroop Tajul-Maathir,p.205. According to Cunningham, he is probably to be identified with Lahangdeo, the fifth king of the list of Hiraman Munshi's Gwalior Namah.B.M.Add. 16709. 7.9a(Cf Habibullah Foundation) See also the version of Motiram and Khushal. I.O.Ms. 860 f.8b.(Cf Ibid).The prince, Sallakshana Sinha, is mentioned in a fragmentary inscription, Discovered in Jhansi, as being engaged in fighting the Jevanas. It is however, without date;Epigraphia Indica,Govt Press,Delhi, I, p. 214-5.

1 Tarikh-i-Farishta, p. 58-59; Kirtane; Hammira Mahakavya, p. 62; Tajul-Maathir, ff. 42b-54a(Cf Habibullah Foundation)

1 Minhaj, p. 140; Farishta, p. 59;Bhagwat Saroop Tajul Maathir,p.225.

1 Fakhre Mudabbir, p. 24. the Tajul-Maathir, f. 176b mentions Aibak's stay in Badaun in 599/1202-3(Cf Habibullah Foundation).

${ }^{1}$ Bhagwat Saroop Tajul-Maathir,p.244, Fakhre Mudabbir, p. 25; Cf. Cunningham; Reports, ii, p. 456 who erroneously asserts that Kalinjar was attacked twice, in 1196 and again in 1202.Farishta, p. 62.

${ }^{1}$ This simpler form of the name found in A.B.M. Habibullah, p. 69 and also in the printed text of B.M. Mss. of The Tabaqat-i-Nasiri, inspite of Raverty's craze for the izafat inserted between Muhammad and Bakhtiyar as a substitute for bin.

${ }^{1}$ N.Lees etal(ed.)Tabakat-i-Nasiri, p. 146-7

${ }^{1}$ Minhaj; p. 147

${ }^{1}$ N.Lees etal(ed.)Tabakat-i-Nasiri, p. 147-8

${ }^{1}$ Ibid, p. 148

${ }^{1}$ D. Chttopadhyaya (ed.); Tarantha's History of Buddhism in India (Calcutta 1980), p. 319.

${ }^{1}$ Ibid.

${ }^{1}$ N.Lees etal (ed.) Tabakat-i-Nasiri, p. 150-1;Richard M. Eaton; Rise of Islam and the Bengal Frontier,12041760,Berkeley and Los Angeles,University of California Press,1993, p. 32, note 10.

${ }^{1}$ Imperial Gazetteer of India,(Oxford, 1908), xii, p. 18; journal of Asiatic society of Bengal,Calcutta. Old series:in two parts separately for Antiquities and Natural Sciences.New series(since 1905): Journal and Proceedings.In progress:Journal of Royal Asiatic Society of Bengal issued separately for Letters, Science and Yearbook. (N.S.), ii, p. 282.

${ }^{1}$ Minhaj, p. 152.

${ }^{1}$ Ibid, p. 154

${ }^{1}$ Bhagwat Saroop Tajul-Maathir,p.273; Minhaj, p. 124.

1 Bhagwat Saroop Tajul-Maathir,p.273; Minhaj, idem, Tarikh-i-Mubarakshahi, p. 12; Haji Dabir;ZafarleWalihi,edited under the title of"'An Arabic History of Gujrat" by E.D.Ross,London,1921; p. 602, See also Reverty, op. cit. p-458, note.

${ }^{1}$ Raverty, op. cit, p. 531, note, 8 argues at great length that the name should really be pronounced as Kabajah, but the above form is confirmed in Hindi script on one of his coins; Journal of Asiatic Society of Bengal, 1887, p. 171. 
${ }^{1}$ Also Aybek, Aybeg, Skt. Shuduvadina, Shutubadina (Indian Antiquary, xix, p. 186; Epigraphia Indica; Arabic and Persian Supplement,Government Press,Delhi(1913-14)(Since 1951 issued as 'Arabic-Persian supplement to Epigraphia India), p. 43)

${ }^{1}$ N.Lees etal (ed.)Tabakat-i-Nasiri, p. 140;M.Hidayat Husaini (ed.) Tarikh-i-Mubarakshahi, p. 14, 16; Ferishta, p. 63.

${ }_{1}^{1}$ Thomas,Chronicles, p. 34, 37: H.Nelson Wright; The coinage and Metrology of Sultans of Delhi (New Delhi, 1974), p. 69.

${ }^{1}$ M.Hidayat Husaini (ed.)Tarikh-i-Mubarakshahi. P. 15;N.Lees etal (ed.)Tabakat-i-Nasiri, p. 140;Ferishta, p. 63;A.M. Husain (ed.)Futuhus-Salatin, vs. 1974-1996.

1 Epigraphia Indo-Moslemica,Govt.Press,Delhi(since 1951 issued as 'Arabic and Persian supplement to Epigraphia India') 1911-12, p. 2.

1 N.Lees etal(ed.)Tabakat-i-Nasiri, p. 141;M.Hidayat Husaini (ed.) Tarikh-i-Mubarakshahi, 15; Cf. Mirat-iJahan Numa, f. 53, which places his death in 609/1212, whereas Aibak's latest inscription is dated Ramzan, 607/1210.(Cf Habibullah Foundation).

${ }^{1}$ Raverty, p. 529, note 4; N.Lees etal (ed.)Tabakat-i-Nasiri, p. 141-2; Ferishta, p. 64; Nelson Wright, coinage and Metrology, p. 69; Defremery and Sanguinetti Ibn Batutah 111, p. 164.

${ }^{1}$ N.Lees etal(ed.)Tabakat-i-Nasiri, p. 141-2.

${ }^{1}$ Defremery and Sanguinetti, Ibn Batautah, III, p. 164. Battuta actually refers to this king as 'Lamlish'. There is a number of variant spellings of the name, but the proper name appears to have been Iltutmish, 'holder of the realm (Cf. S. Digby, 'Iletmish or Iltutmish? A reconsideration of the Name of the Delhi Sultan', Iran, 8 (1970), p. 57-64; Thomas Chronicles, p. 43-44,, 71; Nelson wright, coinage and Metrology, p. 70). In Sanskrit his name was revealed Lititimisi, or he was referred to as Suritan Sri Samasadin or Samusdina, or simply. The 'Turushka lord' (Turushkadhipamadaladan) (Z.A. Desai; 'Inscriptions of the Mamluk Sultans of Delhi', in: Z.A. Desai (ed.); Epigraphia Indica, Arabic and Persian Supplement (1966) (Delhi, 1967), p. 1-18; 'Reference to Muhammadan's AD 730-1320 in: The Journal of Indian History, 15 (1936), p. 177.

${ }^{1}$ Minhaj, p. 179, where it is included in Iltutmishs conquests, it is called Nardin by Utbi,Abu Nasr;Tarikh-iYamini,also called Kitab-i-Yamini,Arabic text,ed.Ali and Sprenger,Delhi,1847, p. 260: For some years the latter Hindu-Sahiya Kings made it their capital for its location see Raverty: op. cit. p. 534, note i., Imperial Gazetteer of India, xviii, p. 349; also Nazim,Muhammad; Life and Times of Sultan Mahmud of Ghazna,Cambridge,1931, p. 91.

${ }^{1}$ Minhaj, p. 164.

${ }^{1}$ Minhaj, p. 174. This date is also, like that on the Daulat Shah Cion, doubtful, for Raverty found 628 in some of the older manuscripts, Haji Dabir, ii, p. 698, however, has 627.

${ }^{1}$ These places are listed in Iltutmish's conquests; Minhaj, p. 179, At Kaman, near Thangir, he built the mosque now known as the Chausat Khamba, See Cunningham; Report, xx, pp. 11 and 56.

${ }^{1}$ Minhaj, p. 236

${ }^{1}$ Minhaj, p. 176,

${ }^{1}$ Epigraphia Indica, Arabic and Persian Supplement, 1913-14, p. 14-15.

${ }^{1}$ Ibid, Epigraphia Indo-Moslemica, 1911-12, p. 3, 27-30; A.M Husain (ed.) Futuhus-Salatin, p. 123-4.

${ }^{1}$ Epigraphia Indo-Moslemica, 1911-12, op. cit; p. 27; Z.A. Desai, 'Inscription of the Mamluk Sultans of Delhi', Epigraphia Indica: Arabic and Persian supplement (1966), ed. Z.A. Desai (Delhi, 1967), (p. 1-18p. 17).

${ }^{1}$ There is a rear coin of Iltutmish which contains only the name of the Caliph and which was probably issued to commemorate the arrival of the Caliphal diploma of investiture (Thomas, Chronicles, p. 46; Nelson wright, Coinage and Metrology, p. 18; N.Lees etal (ed.) Tabakat-i-Nasiri, p. 174; Ferishta, p. 66).

${ }^{1} \mathrm{~S}$. Moosvi;'Numismatic evidence and the economic history of the Delhi sultanate', Proceedings of the Indian History congress (1989-90), p. 207-8.

${ }^{1}$ Minhaj, p. 176.

${ }^{1}$ A.B.M. Habibullah, Foundation of Muslim rule in India, Allahabad, 1961; p. 105.

${ }^{1}$ Minhaj,p.120; Fakhre Mudabbir,p.22.

${ }^{1}$ Minhaj,p.139

\section{References}

[1] Abu Bakr Muhammad Al-Rawandi. b.Ali;Rahatus-Sudur ed,M.Iqbal,Cambridge,1922

[2] Al Biruni,Kitab fi Tahqiqi mali-I-Hind (Hyderabad,India,1958)

[3] Alami.A, Conquetes de Mahmud al- Ghaznawi d'apres le Kitab al Yamini d'Utbi,2 vols (Doctorat d'Etat,Paris,III,1989)

[4] Al-Utbi, Tarikh al-Yamini: Persian translation by Jurbadqani(1206 AD) (Tehran,1334 H)

[5] Al-Utbi,Abu Nasr;Tarikh-i-Yamini,also called Kitab-i-Yamini,Arabic text,ed.Ali and Sprenger,Delhi,1847

[6] Al-Utbi,Tarikh al-Yamini (Delhi, 1847)

[7] Baizawi,Abu Said Abdullah;Nizamat-Twarikh.Bm.Add.16708.f.51a

[8] Bakshi, Nizamuddin; Tabaqat-i-Akbari,(a)ed.De and Husain,3 Vols,Calcutta,1927-41.(b)Trans.B.De.3 Vols Cal.1913-40

[9] Bartold;Turkistan down to the Mongol Invasion,Eng. Trans. By H.A.R. Gibb,London,1928,2nd ed.1958 op.cit, p. 333ff 
[10] Beckwith,C.I., 'Aspects of the Early History of the Central Asian Guard Corps in Islam',Archivum Eurasia.Medii Aevi,IV(1984),

[11] Bosworth,C.E., The Ghaznavids. Their Empire in Afghanistan and Eastern Iran 994:1040, 2nd edition (Beirut, 1973)

[12] Bosworth,C.E.,'The Imperial Policy of the Early Ghaznavids',Islamic Studies 1 (1962)

[13] Bosworth,C.E.,The Early Islamic History of Ghur,Central Asiatic Journal,6 (1961)

[14] Bosworth,C.E.,The Later Ghaznavids,Splendour and Decay: The Dynasty in Afghanistan and Northern India 1040-1186 (Eidenburgh,1977).

[15] Boyle,J.A., (ed). The Cambridge history of Iran, V. The Saljuq and Mongol periods (Cambridge, 1968)

[16] Buhler,G., The Jagaducharita of Sarvanada: a Historical Romance from Gujrat (Vienna,1892),

[17] Ch.Pellat et al.(eds.), The Encyclopaedia of Islam,new edition (Leiden,1954- in progress).

[18] Chand Bardai;Prithviraja Raso,ed.M.V.Pandia and Sam Sundar Das,Nagari Pracharini Sabha, Benaras,1913 vi: also Raj Darshani, f. 49 a.

[19] Chattopadhayaya,B.D., 'Origin of the Rajputs: the political, economic and social processes in early medieval Rajasthan', IHR 3 (1976), repr.in his The Making of early medieval India (Oxford and Delhi, 1994), 57-88.

[20] Chttopadhyaya,D. (ed.); Tarantha's History of Buddhism in India (Calcutta 1980)

[21] Clauson,G.,Turkish and Mongolian Studies(London,1962)

[22] Codrington,K.de.B.,'A Geographical Introduction to the history of Central Asia', The Geographical Journal,CIV (1944),

[23] Dabir Haji:Zafarle-Walihi,edited under the title of"An Arabic History of Gujrat" by E.D.Ross,London,1921

[24] Desai,Z.A., 'Inscriptions of the Mamluk Sultans of Delhi', in: Z.A. Desai (ed.); Epigraphia Indica, Arabic and Persian Supplement (1966) (Delhi, 1967)

[25] Digby,S., 'Iletmish or Iltutmish? A reconsideration of the Name of the Delhi Sultan', Iran, 8 (1970)

[26] Eaton, M. Richard; Rise of Islam and the Bengal Frontier,1204-1760,Berkeley and Los Angeles, University of California Press,1993,

[27] Epigraphia Indica, Arabic and Persian Supplement,1913-14 (Calcutta, 1917; reprint Delhi, 1987)

[28] Epigraphia Indica; Arabic and Persian Supplement,Government Press,Delhi(1913-14)(Since 1951 issued as 'Arabic-Persian supplement to Epigraphia India)

[29] Epigraphia Indo-Moslemica,Govt.Press,Delhi(since 1951 issued as 'Arabic and Persian supplement to Epigraphia India') 1911-12

[30] Escedy,H.,'Tribe and Tribal Society in the 6th Century Empire',Acta Orientalia Hungarica,25 (1972); Golden,P.B., 'Imperial Ideology and the Sources of Political Unity amongst the Pre-Cinggisid Nomads of Western Eurasia', Archivum Eurasiae Medii Aevi,II (1982)

[31] Fakhre Mudabbir(Muhammad b. Mansur b. Said Qurashi);Shajarat (or Bahr) al-Ansab, partial edn. by Sir E. Denison Ross;Tarikh [sic]-i-Fakhr al-Din Mubarakshah (London,1927)

[32] Ferishta,Qasim b. Hindu Khan;Tarikh-i-Ferishta (Lucknow, 1864)

[33] Forbes,A.K.,Rasmala:Hindoo Annals of the Province of Goozerat in Western India,2 vols (London, 1924). (ed. Rawlinson)

[34] Gazetteer of the province of Oudh.3 vols (Lucknow and Allahabad,1877-78)

[35] Golden,P.B.,An Introduction to the History of Turkic Peoples: Ethnogenesis and State formation in Medieval and Early Modern Eurasia and the Middle East (Wiesbaden,1992),

[36] Golden,P.B.'Imperial Ideology and the Sources of Political Unity amongst the Pre-Cinggisid Nomads of Western Eurasia',Archivum Eurasiae Medii Aevi.II (1982),

[37] Habibullah,A.B.M., Foundation of Muslim rule in India, Allahabad, 1961

[38] Hall,J.A. and Jarvie,I.C. (eds), Transition to Modernity: Essays on Power, Wealth and Belief (Cambridge,1992)

[39] Hasan Tajud Din Nizami's;Taajul-Maathir(The Crown of Glorious Deeds), translated by Bhagwat Saroop,saud Ahmad Dehlavi,Delhi,1998

[40] Hodivala,S.H.,Studies in Indo-Muslim history (Bombay, 1939-57, 2 vols)

[41] Hoffmann,H.,'Die Qarluq in der Tibetaischen Literatur',Oriens,III,2 (1950),

[42] Husain,A.M., (ed). Futuh-us-Salatin of Isami (Agra, 1938).

[43] Husian,A.M.,(ed); Futuhus-Salatin of Isami (Agra, 1938)

[44] Ibn Battuta;Kitabur Rahlah,also called,Tuhfatun Nuzzar fi gharaib-il-amsar:ed.(a)Cairo,1870-71, (b)With a French trans.Defremery and Sanguinatti,Paris, 4 Vols,1853-59, (c) Abridged Eng. Trans.H.A.R. Gibb,London,1929, (d) Eng.trans.(of the travels in India,Maldive and Ceylon) by Mahdi Husain,Baroda, 1953 , ii

[45] Imperial Gazetteer of India,(Oxford, 1908),

[46] Ishwariparasad;History of Medieval India,Allahabad,1925

[47] Jackson Peter;The Delhi Sultanate,A Political and Military History,Cambridge University Press, 1999

[48] Journal of Asiatic Society of Bengal, 1887

[49] Journal of Asiatic society of Bengal,Calcutta. Old series:in two parts separately for Antiquities and Natural Sciences.New series(since 1905): Journal and Proceedings.In progress:Journal of Royal Asiatic Society of Bengal issued separately for Letters,Science and Yearbook. (N.S.)

[50] Juwaini Alauddin Ata Malik;Tarikh-i-Jahan Gusha-e-Juwaini,ed. Abdul Wahab Qazwini.2 vols.,London,Gibb memorial series,1912-1916.Vol.III a facsimile edition,by E.D.Ross,London,1931.Eng trans.J.A.Boyle,2 vols,Manchester,1958

[51] Juzjani, Minhaj,Abu Umar b. Siraj;Tabaqat-i-Nasiri,(a) ed.Nasau Lees,Khadim Hussain,and Abdul Hai Bib.Ind.Calcutta,1864.(b)English trans.By H.G.Raverty,2 Vols,Bib.Ind Calcutta,1897

[52] Kirtane, N. Janardan,'The Hammira Mahakavya of Nagachandra Suri', Indian Antiquary (1890)

[53] Kwanten,L., Imperial Nomads: a History of Central Asia,500-1500(Philadelphia,1979)

[54] Mahmood,.T.,'The Dargah of Sayyid Salar Masud Ghazi in Bahraich:Legend,Tradition and Reality',in: Ch. Troll (ed.),Muslim Shrines in India (New Delhi,1984).

[55] Maricq,A. and Weit,G., Le minaret de Djam. La decouverte de la capitale des sultans Ghorides (XII-XIII siecles) (paris, 1959)

[56] Mc Gregor,R.S., Hindi Literature from its Beginnings to the Nineteenth Century (Wiesbaden, 1984)

[57] Mirat-i-Jahan Numa,B.M.Or.1998 f. 50a

[58] Morley,W.H., (ed.),Tarikh-i-Baihaqi (Calcutta,1862)

[59] Mubarakshah, Fakhruddin,(Known as Fakhre Mudabbir);Tarikh-i-Fakhruddin Mubarakshah,ed.E.D.Ross,London,1867, p. 22).

[60] Munshi Hiraman, Gwalior Namah.B.M.Add. 16709.

[61] N. Lees etal.; (eds) Tabaqat-i-Nasiri of Abu Umar al-Juzjani (Calcutta, 1894)

[62] Narain,A.K., The Indo-Greeks (Delhi,1980),

[63] Nazim,Muhammad; Life and Times of Sultan Mahmud of Ghazna,Cambridge, 1931

[64] Nazim.M., (ed.),Zayn al-Akhbar of Gardizi (Berlin,1928), 
[65] Nelson,H. Wright; The coinage and Metrology of Sultans of Delhi (New Delhi, 1974)

[66] Newman,J., 'Islam in the Buddhist Kalacakra Tantra' (Paper presented to the 1989 Annual Meeting of the American Academy of Religions, Annaheim,CA.1989)

[67] Nurul Haqq Dehlavi; Zubdatul-Twarikh,I.O.1805 f.7b

[68] Ojha,Gourishankar.H; Rajputaneka Itihasa,Ajmer,1927

[69] Qazwini Hamdullah Mustaufi; Tarikh-i-Guzidah,Fascimile ed.,Gibb Memorial series, London, 1913

[70] Raverty,H.G; Notes on Afghanistan,London,1880.

[71] Ray,H.C.; Dynastic History of Northern India.3 Vols.Calcutta University 1931-35

[72] S. Moosvi; 'Numismatic evidence and the economic history of the Delhi sultanate', Proceedings of the Indian History congress (1989-90)

[73] S. Qudratullah,S. Fatimi; 'The Twin Ports of Daybul', in Hamida Khuhro (ed.), Sind through the centuries (Oxford and Karachi, 1981)

[74] Sachau,E.C.(trans.),Alberuni’s India (New Delhi,1983)

[75] Sarda,H.N; Ajmer,Historical and Descriptive.Ajmer,1911

[76] Sharma,T.R., Personal and Geographical Names in the Gupta Inscriptions (Delhi, 1978)

[77] Siddiqui,I.H.,Perso-Arabic Sources of Information on the Life and conditions in the sultanate of Delhi (New Delhi, 1992)

[78] Sinor (ed)., The Cambridge History of Early Inner Asia (Cambridge,1990).

[79] Sircar,D.R., Studies in the Geography of Ancient and Medieval India (Delhi,1971)

[80] Sirhindi,Yahya;Tarikh-i-Mubarakshahi,(a)ed.M.Hidayat Husain , Bib.Ind. Calcutta , 1931. (b)Eng. Trans.by K.K.Basu,Baroda,1932

[81] Smith,A.D., The Ethnic Origins of Nations(Oxford,1986)

[82] Stein,M.A. (ed),Kalhana's Rajtarangini (Delhi, 1960)

[83] Tarikh-i-Farishta (Lucknow,1864),

[84] Thattawi Mulla Ahmad and others, Tarikh-i-Alfi,B.M.(a) Or,142,(b) Or,162.

[85] The Journal of Indian History, 15 (1936)

[86] Thomas,Edward;Chronicles of the Pathan Kings of Delhi,London1871

[87] Tornberg,C.J., (ed.),Ibn al-Athir, Al-Kamil fi 1-Tarikh, 12 vols (Leiden, 1853-1869)

[88] Wink Andre,Al-Hind: The Making of the Indo-Islamic World,I.Early Medieval India and the Expansion of Islam,7th-11th centuries (Leiden, 1990).

[89] Wink, Andre,Al-Hind,The Making of the Indo-Islamic World,Vol. II,The Slave Kings and The Islamic Conquest 11th-13th cen.,Oxford University Press(1999) 